\title{
Essais
}

Revue interdisciplinaire d'Humanités

Hors-série 4 | 2018

Stanley Kubrick

\section{The Kubrick Cinematic UniverseMethod}

Rod Munday

\section{(2) OpenEdition}

Journals

Electronic version

URL: http://journals.openedition.org/essais/728

DOI: 10.4000/essais.728

ISSN: 2276-0970

\section{Publisher}

École doctorale Montaigne Humanités

\section{Printed version}

Date of publication: 1 July 2018

Number of pages: 141-156

ISBN: 979-10-97024-04-8

ISSN: 2417-4211

\section{Electronic reference}

Rod Munday, "The Kubrick Cinematic UniverseMethod », Essais [Online], Hors-série 4 | 2018, Online since 01 December 2019, connection on 16 December 2019. URL : http://journals.openedition.org/ essais/728 ; DOI : 10.4000/essais.728 


\section{The Kubrick Cinematic Universe}

\section{Rod Munday}

In this paper, I will explore Kubrick's body of work as a cinematic universe. The concept is particularly associated with the comicbook universes of Marvel and DC and their film franchises. I intend to apply it to a textual analysis of Kubrick's film oeuvre. I define a cinematic universe as a closed system in which the meta-storyworld of "the universe" represents a synthesis of the various storyworlds and iconography of individual Kubrick films, which have hitherto been interpreted separately. I will claim that this meta-Kubrick film, as an analytical object, can tell us something about the Kubrickian, or the sensibilities of the person who created it. However, the Kubrickian is not the same thing as Kubrick the person, the former does not represent the biography of the filmmaker, nor his personality, but rather is an aggregated impression of Kubrick's preferences and values that are communicated via his body of work.

A similar idea to this is outlined by Claude Lefort, ${ }^{1}$ writing from within the framework of auteur theory. Lefort claims that the auteur and the oeuvre represent a reciprocal system, both aspects of which serve as a mutual guarantee. Kubrick himself lends some credence to this idea when he said "I would not think of quarrelling with your interpretation nor offering any other, as I have found it always the best policy to let the film speak for itself."

\section{Method}

The main method I shall use is a form of textual and semiotic analysis, based upon network theory -a discipline whose impact has been amplified due to the rise of the Internet as a mass communications medium. A network

1 Lefort C., Machiavelli in the Making. M.B. Smith (trans.). Evanston, Illinois: Northwestern University Press, 2012, p. 23.

2 Hollis, A. "War and Justice." Saturday Review, December 21, 1957, quoted in Kagan N. The Cinema of Stanley Kubrick, New York: Continuum, 2000, p. 137. 
is defined as an object comprising of both nodes and the links between them. For example, the nodes of a computer network are the individual computers and its links are the hardwire or Wi-Fi connections. Networks appear in many different topographical guises, although the form I am interested in using as a way to structure an analysis of Kubrick films are called "scale free networks." These are naturally evolving networks where a minority of nodes within the network attract many more of the links than other nodes, thus forming hubs. Scale free networks are found in a wide variety of naturally occurring objects, from the cellular level of life, ${ }^{3}$ to the structure of galaxies. ${ }^{4}$

Scale free networks have three main characteristics that identify them. ${ }^{5}$ The first is a phenomenon known as high clustering coefficiency. The nodes of an evolving network are not just randomly distributed but tend to form into groups surrounding one particular node, which is more connected than the rest. ${ }^{6}$ The second is that these clusters then themselves cluster around one particular node that becomes a hub, or the most connected node over the entire network. ${ }^{7}$ The third characteristic is that connectivity over the entire network can be achieved involving very few steps. Communication across a network takes place in the form of a dyadic connection between individual nodes. But due to the presence of both clusters and hubs, communication occurs between any two nodes in the network in a surprisingly small number of steps. This is otherwise known as six degrees of separation, or the small world phenomenon, studied by Stanley Milgram in the 1960 s. $^{8}$ No matter how large or complex the network is, the steps linking its individual nodes remain about the same number. For example, there are just 4.7 steps connecting all the users of Facebook, which has over two billion members. ${ }^{9}$

The network is the cinematic universe itself. Its nodes are the various signs that can be considered meaningful elements within the individual films. Its links are the affinities between nodes that occur in different films. Clusters and hubs in network theory are today called "influencers" ${ }^{10}$, because their opinions

3 Barabási A.L. \& Bonabeau E., "Scale-Free Networks", Scientific American, 2003, 288: p. 60-9.

4 Barabási A.L., Linked: How Everything Is Connected To Everything Else And What It Means For Business, Science, And Everyday Life. New York: Basic Books, 2014, p. 71-2.

5 Zhang Z., Zhou S. \& Chen L., "Evolving Pseudofractal Networks". The European Physical Journal B, 2007, 58(3): 337-344.

6 Watts D.J. \& Strogatz S., "Collective dynamics of 'small-world' networks". Nature, 1998, 393(6684): 440-442.

7 Barabási A.L., Linked: How Everything Is Connected To Everything Else And What It Means For Business, Science, And Everyday Life. New York: Basic Books, 2014, p. 54.

8 Milgram S., "The Small-World Problem", Psychology Today 1 May, 1967: 62-67.

9 Ugander J., Karrer B., Backstrom L. \& Marlow C., "The anatomy of the Facebook social graph", 2011, p. 4. Online, URL: Retrieved from http://arxiv.org/abs/1111.4503 [last accessed 13 Oct. 2017].

10 Kietzmann J.H., Hermkens K, McCarthy I.P. \& Silvestre B.S., "Social media? Get serious! 
set the trends for the whole network. In the Kubrick cinematic universe, the clusters are the pervasive themes found across Kubrick's films and the hub is the sensibility of Kubrick himself, who, like a composer, orchestrates these themes in his work. The nodes are the sign elements found in his films that the digital theorist Espen Aarseth terms "textons". ${ }^{11}$ These are the signs that are materially present in any text, examples of which include instances of dialogue, or elements of the mise-en-scène of a film. The interpretation of textons when viewing a film produces what Aarseth calls "scriptons". ${ }^{12}$ These are the signs created in the mind of the reader from the textons that are available. In digital texts such as videogames, for example, the textons can be reconfigured by the user at the level of the text; however, in traditional media (such as films), textons cannot be altered, although the scriptons that make up the readings of them can differ considerably between one interpreter and another, because the interpretation that a reader makes is unique to them.

In applying these ideas to an analysis of cinematic universes, one can say that the hubs of the universes of comicbook films are the reoccurring characters or events of the meta-narrative. For example, the character of Tony Stark is a hub in the Marvel universe, because his character's timeline intersects with those of many other characters. To extend the concept to an analysis of Kubrick films, we can say that the hubs in this universe are more centred upon common thematics and aesthetics. For example, a candidate hub is the theme of how otherwise perfect systems are let down by human fallibilities. Or how the reoccurrence of symmetric compositions in the mise-en-scène of his films suggests a worldview that interrogates the human condition in an ordered or systematic way.

2001: A Space Odyssey is an exemplary film to demonstrate how an interpretive method that is already applied to an individual film can be scaled up to apply to his entire oeuvre. 2001 comprises a mostly visual text; the language elements that would anchor its meaning to a preferred interpretation ${ }^{13}$, are therefore mostly absent. Consequently, thematic points and ideas are communicated pictorially rather than lexically. The trick at arriving at a satisfying interpretation for the film -one which draws all of its disparate elements together into a coherent explanation - is to link the textons intratextually as a network of signs. An interpreter does this by comparing or contrasting textons found in one part of the film with those found in other parts. In so doing, the interpreter constructs a storyline for the film that organizes its affi-

Understanding the functional building blocks of social media”. Business Horizons, 2011, 54(3):241-251.

11 Aarseth Espen J., Cybertext: Perspectives on Egodic Literature. Baltimore, US: John Hopkins Press, 1997, p. 63.

12 Ibid.

13 Barthes, R., Image, Music, Text. S. Heath (trans.). London: Fontana Press, HarperCollins Publishers, 1977, p. 39-40. 
nities and dissaffinities as scriptons into a covering explanation. For example, the prehistoric scenes in the "Dawn of Man" section are connected to events that happen later in the narrative: the glowing eyes of the leopard are linked to the glowing eyes of HAL, and this trope identifies them both as threats to the existence of humanity. Another instance is how the barren landscape of the prehistoric hominids is linked to the barrenness of the lunar landscape (or to outer space), both of these extraterrestrial environments suggesting similar challenges for human species survival.

If these connections are not made, 2001 would appear to interpreters to be just a series of random unconnected events. So the hermeneutic work involves joining both contingent and associative textons within an individual film to create a coherent series of scriptons that explains them. I suggest this method can be expanded to look for connections across the whole of Kubrick's body of work. Furthermore, it is often the case that interpreters will draw upon other semiotic elements that occur outside of the film text to endorse their coherent interpretation. For example, in 2001, a commonly discussed connection links the various stages of humanity (hominid, contemporary and starchild) to the stages outlined in the philosophy of Nietzsche. This, however, is a riskier strategy, since the texton-scripton relationship has been stretched beyond the intratextual into the realm of the intertextual. Nevertheless in some cases, Kubrick's textons actually seem to suggest such associative readings. For instance, by the use of Richard Strauss tone poem, "Thus Spake Zarathustra" as the title music for 2001.

A full analysis is beyond the scope of this paper. I will begin by focusing on just three films: Fear and Desire (1953), Killer's Kiss (1955), and The Killing (1956), as the springboard for connections that will range over the entirety of Kubrick's oeuvre. I have chosen these films because they are the least written about.

\section{Fear and Desire}

Kubrick's first feature film, Fear and Desire, made when he was twenty four years old ${ }^{14}$, is a contested addition to the Kubrick oeuvre, because of the efforts the director made to disown it; allegedly attempting to purchase all the copies so that he could destroy them. ${ }^{15}$ While the film is very much an apprentice work, Kubrick's moody black and white photography stands out. However, his handling of the performances and elementary mistakes made with the editing betray the fact that he was a filmmaking novice.

14 Life, "A Silent Virginia is Discovered”, Life Magazine (1 $1^{\text {th }}$ May, 1953), p. 122 \& 125.

15 Rhodes Gary D., Stanley Kubrick: Essays on His Films and Legacy. Jefferson: McFarland \& Company Inc., Publishers, 2008, p. 30. 
Fear and Desire takes place in an unspecified country at a time when a war is raging. Four soldiers are stranded behind enemy lines. The film begins with a sonorous monologue that foregrounds the films status as a fiction.

There is war in this forest. Not a war that's been fought, or one that will be, but any war. And the enemies who struggle here do not exist, unless we call them into being.

The reflexive strategy of foregrounding the film's fictional status is mirrored in other places in the narrative. Kubrick and his writer, Howard Sackler, make frequent references to Shakespeare's play, The Tempest -a play that is also concerned with its ontological status as a fiction. The opening narration, for example, echoes the themes of Prospero's famous "our revels now have ended" speech in Act 4 Scene 1: "Yea, all which it inherit, shall dissolve; And, like this insubstantial pageant faded, Leave not a rack behind." The Tempest also provides the frame for Sidney's descent into madness. Sidney, the youngest and most childlike of the four soldiers, is given the duty of guarding an enemy captive (credited only as, "the girl"). She is restrained by being tied to a tree, like Ariel in The Tempest, trapped by the witch Sycorax. Sidney's madness involved quoting from the play and when he eventually kills the girl, he blames her death on the magician (Prospero). At the end of the film, Sidney is found wading in a river singing Ariel's song, "Full Fathom Five." An additional more oblique reference to The Tempest appears in the scenes between the enemy General and his dog, "Proteus". Proteus is named after the ever-changing god of the sea, whose name means "the first being"16, the source for the adjective "protean". Ideas of metamorphosis and the sea connects to the theme of Ariel's song to the god, Proteus, who is also used by James Joyce as the title for the third part of his novel, Ulysses, as a metaphor for "the fluctuations of consciousness." 17

While these allusions are interesting, Kubrick does not manage to find a dramatically satisfying way to weave them into the narrative. Consequently it is difficult to know how to interpret them. The filmmaker is clearly ambitious. He strives for gravitas and sophistication. But he lacks the subtlety and the artistry to achieve his aims. For example, in the film's opening narration he uses an authoritative voice to tell us to doubt the film's ontological authority. Kubrick thereby undercuts his own authority as a filmmaker, through telling us of his reflexive intentions. In his later works, he would find ways to hide this crude didacticism. In Barry Lyndon, for instance, the narration is used as an ironic counterpoint to the events shown in the narrative. ${ }^{18}$ The pronounce-

16 Jung C.G., Kerényi K., Science of Mythology: Essays on The Myth of The Divine Child and The Mysteries of Eleusis, R.F.C. Hull (trans.). London: Routledge, 2002, p. 58.

17 Spinks L., James Joyce: A Critical Guide. Edinburgh: Edinburgh University Press, 2009, p. 102.

18 Ciment M., Kubrick: The Definitive Edition. London: Faber and Faber, 1999, p. 170. 
ments of the Thackerayan narrator are constantly contradicted by the events that are shown in the film. ${ }^{19}$ This technique undermines the authority of the narrator, through persuading audiences to question the trustworthiness of the narrative, without directly telling them to do so.

Fear and Desire is an instructive film because it demonstrates that Kubrick was always interested in incorporating big themes into his stories, therefore countering accusations that his admirers are suffering from interpretive overreach by reading too much into them. In Fear and Desire the allegories and symbolism are blatant. Kubrick in later life would find more sophisticated and subtler ways to disguise them. However, he remained the ambitious and intellectually curious person who was the director of Fear and Desire. In his preface to the published scripts of The Dekalog, Kubrick discusses that, "very rare ability of writers and directors who are able to dramatize their ideas rather than just talking about them." ${ }^{20}$ In Fear and Desire he had clearly not mastered this ability yet.

In his subsequent films, Kubrick deploys many reflexive strategies to separate an audience's intellectual appreciation from their emotional engagement. Like Bertolt Brecht, he would specialise in alienation effects. ${ }^{21}$ Reflexivity operates across a number of dimensions in his films. For example, stylistically the sugar-glass bottles and the break-away balsa-wood furniture featured in the fight between Alex's Droogs and Billy Boys gang in A Clockwork Orange are reflexive because they recall many of the standard gags used in the choreography of saloon bar brawls from Classical Hollywood Westerns. He also shot Alex's daydream of a crucifixion scene in the style of a Hollywood Biblical epic -similarly Kubrick remarked that the characters of Dr Strangelove and Dr Zempf from Lolita were parodies of movie clichés about the Nazis. ${ }^{22}$ This preference for stylistic artifice is also shown in A Clockwork Orange with the obvious rear projection used in the Durango 95 scenes, and in the self conscious use of dialectical montage to represent Alex's masturbatory daydream sequence -which include the intercutting of other films- the hanging scene from Cat Ballou (Silverstein 1965) and the rocks falling on cave people from Creatures the World Forgot (Chaffey, 1966). These techniques are the visual equivalent to the phrase, "it's only a movie"; they function both to show the full horror of Alex's actions, but also to soften them sufficiently, so that the anti hero character can still serve as a sympathetic protagonist.

19 Miller M.C., "Kubrick’s Anti-Reading of The Luck of Barry Lyndon”, Comparative Literature, 1976, 91(6): 1360-1379.

20 Kubrick S., "Forward”. Kieślowski Krzysztof \& Piesiewicz Krzysztof, Decalogue: The Ten Commandments. London: Faber \& Faber, 1991, p. vi.

21 Esslin M., Brecht: A Choice of Evils. London: Eyre \& Spottiswoode, 1971, p. 129.

22 Ciment M., Kubrick: The Definitive Edition. London: Faber and Faber, 1999, p. 156. 
Kubrick made frequent references to his previous films in his oeuvre. In Lolita, for example, Quilty, dressed in a sheet, declares that he is Spartacus, and asks Humbert if he has "come to free the slaves or something?" In A Clockwork Orange, the soundtrack to 2001: A Space Odyssey is prominently displayed in the record store that Alex visits. And in the same film, the Ludovico serum labelled as "serum 114" -is a pun on the "CRM 114", the communications scrambling device featured in Dr Strangelove. Finally in Barry Lyndon, the painting that Barry wants to purchase is by the artist Ludovico. There is even a subtle reference to Fear and Desire in Eyes Wide Shut. Alice Hartford watches the film Blume In Love (1973) on television as she phones her husband Bill. The film is directed by Paul Mazursky, who played Sidney in Fear and Desire. Its title also references Joyce's Ulysses. In Mazursky's film Blume (a play on Joyce's Leopold Bloom) is a man who is trying to come to terms with his divorce, which connects to the central theme of marriage and infidelity in Eyes Wide Shut.

The main dramatic interest in Fear and Desire comes from the juxtaposition between the motives of the soldier, Mac, and those of the unnamed enemy General. The film's central theme is a striving for significance in an otherwise uncaring universe. This is explored through the motif of self-sacrifice. Mac's idealism is contrasted with the weary cynicism of the General, through the intercutting of their scenes. In proposing his idea to assassinate the General, Mac speaks directly about his life to his commanding officer, Lieutenant Colby. He says: "Here I am. I'm 34 years old. I've never done anything important. When this is over I'll fix radios and washing machines." Later, when Mac is paddling down the river to meet his destiny, he says in a voice-over narration, "It's better to roll up your life into one night than to be hurt with all the separate hates exploding day after day." Meanwhile, the General in his cabin meditates on the futility of his power in a speech addressed to his Captain: "Frankly, I still become uneasy when I find myself trapped directing the courses of frightened men. I cannot quite admit that it is I who am creating a slaughter in this abyss." Both characters are shown to be imprisoned by their respective social positions. Both are trapped between the twin polarities of a fear of consequences and a desire for consequentiality.

The futility of war theme is one that Kubrick will return to again and again. Like Joker in Full Metal Jacket, Mac and the General are in a "world of shit", not of their making. And like the soldiers who are sacrificed in Paths of Glory, or the millions who die at the end of Dr Strangelove, they are people who are the victims of forces beyond their control - a failing that Kubrick suggests is hardwired into the human condition itself. This sense of futility as a motivation for human heroism and anxiety is also present in films that are ostensibly not about war. For example, in 2001:A Space Odyssey it is referenced in the central preoccupation of the film: the question of the possibility of alien life. Kubrick stated in a Playboy interview promoting 2001 that: "The 
very meaninglessness of life forces man to create his own meaning... however vast the darkness, we must supply our own light." ${ }^{23}$

\section{Killer's Kiss}

Killer's Kiss (1955) is a contemporary Film Noir, dealing with boxing and gangster life in New York City. It was again written by Howard Sackler, this time in collaboration with Kubrick. It is a far more straightforward genre picture than Fear and Desire. The story of Killer's Kiss is essentially a fairy tale; the good knight, Davey Gordon -a boxer in the twilight of his career- sets out to rescue a princess, Gloria, from the amorous clutches of a vicious ogre, Vinnie Rapallo, a part-time gangster, who is also the owner of the taxi-dance hall where Gloria works.

As a means to emphasise his virtue, Davey Gordon is given a corny backstory worthy of Clarke Kent. We discover, through letters and telephone calls, that Davey grew up on a farm in Seattle with his Uncle George and Aunt Grace, both of whom yearn for him to return home again. As was the case with Fear and Desire, the photography, lighting and composition of the images in Killer's Kiss is strikingly accomplished, and in marked contrast to the acting, writing and editing. However, Kubrick shows that he is a quick study as a filmmaker, and demonstrates a better understanding of pacing and drama than in his previous work, especially in its climatic last quarter and in the boxing match featuring Davey Gordon.

Boxing -a staple subject of Kubrick's photography work with Look and also of his first short film, Day of the Fight (1951) - features strongly in the narrative. Kubrick covers the fight scenes with roving handheld camerawork and the use of a subjective point of view, which recalls both the fight scene between Alex and the Cat Lady in A Clockwork Orange, and the fight between Barry and O'Toole in Barry Lydon.

The director of Killer's Kiss is clearly not afraid to experiment with film techniques. For example, Davey Gordon has a nightmare, which is depicted in the form of a startling tracking shot through the backstreets of New York City, in negative, and accompanied by a woman's scream. The movement of this tracking shot and its abstract expressionism anticipates the stargate sequence from 2001: A Space Odyssey.

Foreshadowing events in the narrative, a favourite storytelling technique of Kubrick, is also present in this film. Kubrick was attracted to this technique because it minimised the effect of surprise. As he stated in an interview with Michel Ciment: "What is important is not what is going to happen, but

23 Nordern E., "Playboy Interview: Stanley Kubrick", 1968, in Stanley Kubrick Interviews, Gene D. Phillips (ed.). Mississippi: University Press of Mississippi, 2001, p. 47-74. 
how it will happen. [...] to gain a greater sense of inevitability and a better integration of what might otherwise seem melodramatic or contrived." ${ }^{24}$ In Killer's Kiss, the entrance to the taxi-dance hall is at the end of a long flight of stairs where a sign that reads, "watch your step" is prominently displayed. Undoubtedly the presence of this sign is serendipitous, given the guerrilla filming techniques that Kubrick used. However, its presence symbolises the sense of dread faced by Gloria. In later films, Kubrick would utilise foreshadowing frequently. In 2001: A Space Odyssey, the point of view shot of the astronauts' lips moving reveals to the audience that HAL knows they are plotting against him. Similarly the scene depicting the strained marriage at the beginning of The Shining already suggests fault lines that will open up later in the narrative. Finally the death of Barry's son, Bryan, in Barry Lyndon, removes all sense of surprise and shock over the tragedy and lends instead a sense of inevitability about Barry's impending downfall. The narrator also underscores this sense of fatalism through dramatic irony.

The climax of Killer's Kiss is a fight scene between Gordon and Rapallo that takes place in a warehouse full of tailor's mannequins. It is a scene that attests to Kubrick's fascination with masks. At the end of the fight Gordon spears Rapallo and Kubrick cuts to the face of one of the mannequins. This is a shot choice that is recapitulated in $A$ Clockwork Orange, with a crash zoom into a painting as Alex kills the Cat Lady. The mask motif is one that will appear in many Kubrick films. In The Killing, Sterling Hayden wears a clown mask when robbing the racetrack. Alex's droogs wear masks in A Clockwork Orange when they invade the homes of both the Writer and the Cat Lady. And the Somerton orgy sequence in Eyes Wide Shut depicts a masked ball, with the rich and powerful disguised by striking Venetian and expressionistic face coverings. As Roger Caillois points out, masks have long been associated with erotic fetes and with conspiracies. ${ }^{25}$ The mask liberates its wearer from social constraints, in a world in which sexual and power relationships are otherwise taboo. In addition to actual masks, Kubrick is also drawn to the face depicted as a mask. Especially in times of heightened emotional intensity, his characters wear the rictus grins and frozen expressions of both agony and ecstasy. Notable examples of this trope are the painted face of Dolores Haze in Lolita in her confrontation with Humbert, the astronaut Bowman as he prepares to blast through the airlock in 2001, and Jack's famous "Here's Jonny!" line as his head appears through the shattered bathroom door in The Shining. Masks are also part of the miseen-scène of Kubrick films. In the scenes that take place in the derelict casino in $A$ Clockwork Orange, the sides of the stage are framed by two enormous

24 Ciment M., Kubrick: The Definitive Edition. London: Faber and Faber, 1999, p. 170.

25 Caillois R., Les jeux et les hommes (Man, Play and Games). M. Barash, (trans.). Chicago, IL: University of Illinois Press, 2001 (1958). 
carnival masks, their comic, and exaggerated features are associated with indecencies, jostling, provocative laughter, exposed breasts, mimicking buffoonery, and a permanent incitement to riot. ${ }^{26}$ Also, masks feature in the apartments of Marian's dying father and Domino the prostitute in Eyes Wide Shut.

On many occasions throughout his oeuvre, Kubrick uses the dichotomies between the sacred and profane to shine a light on the otherwise private aspects of the human condition. The Kubrick Cinematic universe is, for the most part, a Godless place, but one in which the vestiges of a divine absence are to be marked everywhere, in the rituals that Kubrick's characters perform. As with his fascination for bathrooms (which arguably perform a similar functions to masks, in that they hide the user's identity), Kubrick focuses on these secular rituals as ways to reveal hidden facets possessed by his characters. Oscar Wilde said "Man is least himself when he talks in his own person. Give him a mask, and he will tell you the truth." ${ }^{27}$ And Kubrick incorporates this insight into his storytelling.

\section{The Killing}

The Killing, based on Lionel White's (1955) novel, Clean Break, is the first Kubrick film to be adapted from another source. The film's script represents a massive leap forward in quality from his earlier work. In his later works Kubrick would favour adaptation over original screenplays, commissioning material from writers to develop stories he could later turn into films. Being able to analyse a completed narrative played to his strengths as a filmmaker. Like planning ahead in a chess game, he could strategise the best way to present the scenes and foreground the thematics of the narrative. He excelled at finding visual ways to dramatise the psychology and interiority of novels. The Killing demonstrates Kubrick's mastery over the complex, multi-threaded narrative. The Robbery itself is a meticulously handled operation and Kubrick manages to integrate all of the members of his large ensemble cast into a satisfying drama, where none of the roles seem superfluous or underwritten. In a novel technique for the time Kubrick elects to tell this story out of temporal sequence, an artistic decision that helps to foreground the dramatic irony of Johnny Clay's predicament, as the robbery unravels. This film also introduces the pervasive Kubrickian theme of the perfect operation that is thwarted by human fallibilities. This is a theme that is revisited, notably in Lolita, Dr. Strangelove, 2001: A Space Odyssey, and A Clockwork Orange, although there are traces of it in all his works.

26 Caillois R., Les jeux et les hommes, (Man, Play and Games). M. Barash, (trans.). Chicago, IL: University of Illinois Press, 2001 (1958), p. 130.

27 Wilde O., "The Critic as Artist", Complete Works, Vol. 4, Robert Ross (ed.). Massachusetts: Wyman Fogg, 1921, p. 99-226. 
The Killing also marks the debut of another pervasive trope in the Kubrick cinematic universe -the Kubrickian anti-hero. From Lolita onwards, Kubrick displays a preference for flawed protagonists. Unlike other auteurs, such as Fellini with his frequent casting of Marcello Mastroianni, Bergman with Max von Sydow, Tim Burton with Johnny Depp, or David Lynch with Kyle MacLachlan, Kubrick is an auteur who in many of his films does not present the image of a sympathetic protagonist. His heroes tend not to be virtuous, nor particularly admirable people. In some cases, such as Lolita, A Clockwork Orange, and The Shining, they are monsters. Notable exceptions to this trend are found in his work with Kirk Douglas, in Paths of Glory, and Spartacus, where the real dramatic intrigue is provided by the machinations of the powerful generals and senators who oversee the fates of the otherwise noble protagonists. Even in 2001: A Space Odyssey, the ostensible hero roles of Bowman and Poole are realised, not through their nobility or dramatic passions, but through the systematic competences that would be expected of those who would occupy such positions.

The antihero of The Killing, Johnny Clay, is a professional criminal, although he is presented a little too sympathetically in the narrative for his criminality to be entirely credible. The moral universe of The Killing is one in which bad deeds must not go unpunished. Possibly Kubrick was anxious about maintaining audience sympathy, so he includes several scenes where Johnny's virtues are fulsomely praised by other characters such as Fay, Marvin, and Maurice. In later films, Kubrick would gain more confidence as a storyteller and make his hero less overtly likable and more interesting, so that the narrative did not suffer whether audiences cared for them or not. Kubrick would discover that he could be a more effective moralist if he confronted hegemonic moral frameworks rather than endorsing them. By placing audiences in the duplicitous position of sympathisers, Kubrick allows a productive tension to develop between the emotions that his films elicit and the ideas they raise. Kubrick's cinematic universe is one in which immoralities produce a sense of cognitive dissonance. The psychologist Leon Festinger defines this as the struggle for internal consistency when a person is presented with inconsistent events. ${ }^{28}$ Kubrick uses this dramatic technique to place moral questions at the forefront of his narratives. In The Killing, for example, one of the characters, Maurice, a chess-playing wrestler, becomes a kind of conduit who articulates this very Kubrickian perspective.

Johnny, you have not yet learned that you have to be like everyone else. The perfect mediocrity. You know, I often thought that the gangster and the artist are the same in the eyes of the masses. They're admired and hero-worshipped, but there is always present an underlying wish to see them destroyed at the peak of their glory. 
This anti-mediocrity theme also underpins Mac's speech in Fear and Desire. As David Gerrard points out, ${ }^{29}$ Kubrick also spoke about this theme in a 1957 interview: "the criminal and the soldier at least have the virtue of being against something... in a world where many people have learned to accept a kind of grey nothingness." ${ }^{30}$ The admiration Kubrick felt for the criminal, the soldier, as well as for the artist is one directed at society's outsiders. In challenging hegemonic norms, these characters have the potential to jolt people out of their complacency and to address issues of true existential import. But, in his later films Kubrick became more subtle in his presentation of this theme. His characters for the most part remain outsiders, but they do not speak of their predicament so directly. They lie, they euphemise; they mask their condition in obfuscation. For example, Bill Harford in Eyes Wide Shut repeating back what other characters have just said to him, the repetition functioning to cast their words in an ironic new light through the partly naïve, partly knowing doubling, or Jack Torrance in The Shining, burying his anger in platitudes in his conversation with Lloyd the barman. The challenge to hegemonic norms is only occasioned by the narrative in these films, their ideas are dramatised in the situation the characters find themselves in, rather than being spoken of directly. This was the main lesson Kubrick learnt from making Fear and Desire.

A final important theme of The Killing is the loveless marriage between George and Sherry Peatty (their names a play on petty). George and Sherry are the first in a long line of Kubrick screen marriages, from Spartacus to Eyes Wide Shut. Marriage for Kubrick is depicted as a domestic battleground, that mirrors the director's interest in the theme of war in the public sphere. Kubrick uses marriage not just to explore issues of fidelity and betrayal, but also to unmask the complex motivations and failings of the human condition. The novelist James Ellroy, in a conversation with his wife, stated, "It's easy to write the hot fast love story where the man meets the woman... but the long haul of monogamy that's something else." ${ }^{31}$ Kubrick's focuses on this challenge rather than on romance. Kubrick wrote in 1960 the one thing that has always disturbed him is the endings of films, because they tend to introduce a false note: "When you deal with characters and a sense of life, most endings appear to be gratuitous." 32 This is what separates his earlier work -especially Killer's Kiss

29 Gerrard D., "The Heard and Self Reflexiveness". The Kubrick Site, 1999. Online URL: http:// www.visual-memory.co.uk/amk/doc/0015.html [last accessed 13 Oct. 2017].

30 Hollis A., "War and Justice." Saturday Review, December 21, 1957, quoted in Kagan N., The Cinema of Stanley Kubrick. New York: Continuum, 2000, p. 137.

31 Ellroy J., "Feast of Death". BBC Arena Documentary, directed by Vikram Jayanti. BBC, 2001. (The quotation comes 43 minutes and 14 seconds into the film).

32 Kubrick S., "Kubrick's, 'Notes on Film'”. The Observer Weekend Review. $4^{\text {th }}$ December, 1960, p. 21. 
and The Killing- from his later films. The moral universe in which Kubrick's stories are set becomes more ambiguous and less certain as his confidence as a filmmaker and the opportunities afforded him to tell such stories increased.

The work of making meaning is something that is often left for audiences to decide. In his depiction of marriage, Kubrick was not a polemicist. He was happier showing the way things are between men and women rather than presenting an idealised vision of how they should be. In this regard, he was often accused of misogyny, in the critical responses to The Shining, notably by Stephen King. ${ }^{33}$ Critics picked up on the fact that the character of Wendy is not framed according to the grammatical conventions of Hollywood films. Like Bowman and Pool she is not heroic, although critics miss how capable she is, running the hotel and then saving Danny and herself from Jack. Kubrick's critics accuse him of misogyny, not because of what is shown on screen, but because of his reluctance to sentimentalise or idealise. Compared to his later depictions of married life, the marriage in The Killing is easily read according to the conventions of Hollywood Film Noir. And yet there is something in the duplicity, inventiveness and intelligence of Sherry, the wife, that starts to sketch out an approach that will later transcend Hollywood conventionality. As with his moral outlook, Kubrick realised that it was far more dramatic to show behaviour and not to explain it. This desire is most successfully realised in the character of Alice from Eyes Wide Shut, whom Thomas Allen Nelson calls the most "complex and layered" and "the strongest of all of Kubrick's female protagonists." 34

Killer's Kiss marks the beginning of the truly Kubrickian film; a film in which the director's strengths and his vision combine into a work that not only excels because of its photography, but also because of the director's command of visual storytelling. Kubrick would make other similar "quantum leaps" in the quality of his technique during the course of his career. But after The Killing the presence of his strong personal sensibility, that of an endlessly curious moral satirist would start to become more apparent in his work.

When you consider the totality of a director's oeuvre as a cinematic universe, it also creates an image of the director as the sovereign of that universe. In this paper, I have utilised network theory to begin the task of identifying the links that connect the hubs, which I have identified as the dominant themes and aesthetics found in Kubrick's work. In different pheno-

33 Barry D., "Stephen King Hates The Shining Because It's Misogynistic". Jezebel, 2013.Online, URL: https://jezebel.com/stephen-king-hates-the-shining-because-it-s-misogynisti-1361182451 [last accessed 10 Jan. 2018].

34 Nelson T. A., Kubrick: Inside a Film Artist's Maze. Bloomington: Indiana Univ. Press, 2000, p. 296. 
mena across many domains, scale free networks have been identified as a naturally occurring mode of self-organisation..$^{35}$ In the context of semiotics, scale free networks are a candidate for the deep structures that underpin the organisation of meaningful systems. ${ }^{36}$ In subsequent papers I hope to revisit this topic to construct a more complete picture of this universe.

It has not been the aim of this exercise to impose a kind of homogeny upon Kubrick's work, at the expense of its diversity. The Kubrick cinematic universe is a complex analytical object. As a network, it contains hubs but also nodes that are not thematically conjoined to any others. Kubrick was a director who constantly tested the boundaries, including those of his own aesthetics and thematics. The main instances of affinities I have identified so far include a preference for stories about war and conflict, a liking for masks, the antagonism for mediocrity, and a self-reflexive quality. However, there is much to be discovered that lies outside any of these patterns. Indeed there are also many instances where the texton elements in his films can be read against the grain of the interpretive scriptons offered here.

A primary interest in exploring the Kubrick Cinematic Universe has been to regulate the analytical discourse surrounding Kubrick and his films. This is not to limit the study of Kubrick to a few reoccurring tropes, but rather to strike a balance between the expansionist discourses of runaway fan interpretations and the overly reductive perspectives associated with Kubrick's filmmaking colleagues. Both of these perspectives can be limiting in their own way, because both attempt to foreclose further discussion. However, the quality that really drew me to Kubrick's films in the first place was the seemingly limitless interpretive possibilities that they offered. The horizon shrinks to the dimensions of the perceiving mind, and I discovered through an appreciation of his films that my horizons haves been greatly expanded. I think this is his true legacy as a filmmaker, as well as the gift he gives to his admirers. The intellectual pathways which are opened up by visiting the Kubrick cinematic universe is at the root of the pleasure of being an admirer of his work.

Rod Munday

Aberystwyth University odm@aber.ac.uk

35 Barabási A.L., Linked: How Everything Is Connected To Everything Else And What It Means For Business, Science, And Everyday Life. New York: Basic Books, 2014, p. 78.

36 Chandler D., Semiotics the Basics. (Third Edition). London: Routledge, 2017, p. 117. 


\begin{abstract}
My paper is an attempt to diagram Kubrick's body of work as a cinematic universe. Cinematic universes initially emerged in fan discourses as ways to expand the storyworlds of comicbook, film and television texts, however, they have more recently been taken up by media producers as the bases of successful cinema franchises, for example, the new "Star Wars" Sagas. Out of these instances, a definition of a cinematic universe can be elaborated. It is a closed system in which the meta-storyworld of "the universe" represents a synthesis of various component storyworlds which have hitherto developed separately and in isolation.

This paper applies insights from the study of network topology to the textual study of Kubrick's films. The internet is an example of a self-organizing system, which is the object of a branch of mathematics know as network topology. What was hitherto thought of as a random distributed network, consisting of computer servers and links, is now known to be a scale-free network; a self organising system of hubs, clusters and short-path-lengths. Such self-organizing systems were also found to exist in a wide range of phenomena, from the structure of cells, to galaxies. So it can be inferred that all modes of self-organisation follow this pattern of organisation. I intend to study Kubrick's thirteen films as a scale-free network -in this paper, I focus on just the first three- applying principles from network topology to explore commonalities and differences between them. The goals of this exercise are twofold: to discover the hubs of Kubrick's cinematic universe; those themes and tropes through which is body of work can be understood, and through this knowledge, to infer the central concerns of Kubrick, the filmmaker. This approach represents, therefore, a new method to study the work of a filmmaker as an auteur, through their body of work, or oeuvre.
\end{abstract}

\title{
Keywords
}

Comic-book universes, network topology, scale-free-networks, the Kubrikian, auteur theory.

\section{Résumé}

Cet article explore l'œuvre de Kubrick en tant qu'univers cinématique. Le terme d'univers cinématique origine chez les fans de comics, de films et de séries télévisées désireux de perpétuer un univers narratif, et a récemment été récupéré par les producteurs de franchises cinématographiques à succès telles que la saga Star Wars. Ces utilisations du terme permettent d'en proposer une définition, soit un système clos dans lequel une méta-narration de cet " univers » représente la synthèse de diverses narrations jusqu'alors développées séparément et isolément. Nous appliquerons les concepts issus de la topologie des réseaux à l'étude textuelle des films de Kubrick. L'internet offre un exemple de système auto-organisé qui fait l'objet d'une branche des mathématiques appelée topologie des réseaux. Ce qui était auparavant envisagé comme un réseau de distribution aléatoire (constitué de serveurs informatiques et de réseaux) est désormais compris comme un réseau invariant d'échelle, une plateforme de correspondances auto-organisée. Ces découvertes furent appliquées à l'étude de nombreux phénomènes allant des cellules aux galaxies. On peut ainsi inférer que tout mode d'auto-organisation suit ce même schéma. Nous étudierons par conséquent le corpus filmique de Kubrick comme un réseau invariant d'échelle (en nous concentrant sur ses trois premières œuvres pour les besoins de cet article) et appliquerons les principes de la topologie des réseaux afin d'en explorer les points communs et les différences, et ce avec un double objectif : il s'agira de découvrir les correspondances auto-organisées de l'univers kubrickien (ces thèmes et motifs grâce auxquels l'œuvre trouve son unité), et d'en déduire les questionnements centraux du cinéaste Kubrick. Cette approche explore ainsi une nouvelle méthode permettant d'étudier le travail d'un auteur en se concentrant sur son corpus plutôt que sur une œuvre individuelle.

\section{Mots-clés}

Univers de comics, topologie des réseaux, réseau invariant d'échelle, auteurisme kubrickien. 


\section{BIOGRAPHICAL NOTE}

Rod Munday is a lecturer in new media at Aberystwyth University. He worked for twenty years television post production. He has worked on programmes including Band of Brothers (2001) and The X Factor (2004-2010). He also worked as a web designer for two years on sites such as Greenpeace International and The Royal National Theatre. He has curated The Kubrick Site since 1999 and started the alt.movies.kubrick group on Facebook, which has over 1300 members. He is the co-author with Daniel Chandler of A Dictionary of Media and Communication (Oxford University Press, 2011) and has written a chapter on videogame music included in the volume, Music Sound and Multimedia: From the Live to the Virtual, Edited by Jamie Sexton (Edinburgh University Press, 2007). 